Webbia 67(1): 93-99. 2012

\title{
Notes on some Cyperaceae from Gran Canaria (Canary Islands, Spain)
}

\author{
FILIP VERLOOVE \\ National Botanic Garden of Belgium \\ Domein van Bouchout, B-1860 Meise, Belgium \\ filip.verloove@br.fgov.be
}

Accepted 26 March 2012

Osservazioni su alcune Cyperaceae di Gran Canaria (Isole Canarie, Spagna) — A seguito di raccolte e nuove informazioni d'erbario riguardo alcune entita' critiche di Cyperaceae di Gran Canaria (Isole Canarie, Spagna) sono emerse novita' di interesse floristico. Precedenti asserzioni sulla spontaneita' di Cladium mariscus e Cyperus michelianus vengono qui considerate erronee e attribuibili a C. jamaicense e C. pygmaeus. Kyllinga brevifolia viene citata per la prima volta per Gran Canaria. Viene discussa inoltre la identita’ di Fimbristylis ferruginea per Gran Canaria.

Key words: Cyperaceae, Flora of Canary Islands, Gran Canaria, Spain.

The Cyperaceae family accommodates about 92 genera and 4450 species and has a nearly cosmopolitan distribution (Mabberley, 2008). Relatively few species are of economic, ethnobotanical or horticultural importance (Simpson \& Inglis, 2001) or are significant weeds (Bryson \& Carter, 2008). However, many of the latter are rapidly spreading beyond their native distribution range and now occur throughout the warm-temperate and (sub-) tropical regions of the world. Moreover, many genera of the Cyperaceae are notoriously difficult in terms of identification, taxonomy and/or nomenclature. Recent investigations by the author (in the field as well as in the herbarium) revealed several interesting data on non-native Cyperaceae in southern Europe (see for instance Verloove, 2010b; Verloove \& Sánchez Gullón, 2010; Verloove \& Soldano, 2011).

As a result of fieldwork in Gran Canaria (Canary Islands, Spain) in November 2011 some corrections, additions and/or specifications are required on the inventory of Cyperaceae of this island. Records of two supposedly native species (Cladium mariscus and Cyperus michelianus) turned out to be, at least in part, ascribable to related non-native look-alikes, respectively Cladium jamaicense and Cyperus pygmaeus. The pantropical turf weed Kyllinga brevifolia was observed, apparently for the first time, in Gran Canaria. Finally, the exact identity of plants from Gran Canaria known as "Fimbristylis ferruginea" is discussed.

The present study shows, once again, the importance of an accurate identification of critical plant species. Previous research already emphasized on socalled "invaders in disguise" (Verloove, 2010a): nonnative, usually weedy species that are much reminiscent of ordinary native species and therefore pass unrecorded for quite a long time. Digitaria violascens, for instance, has become a common weed in many areas of southwestern Europe where it was confused for decades with $D$. ischaemum. Likewise, records of the critically endangered Eleocharis carniolica in natural habitats in northwestern Italy turned out to belong, at least in part, to the Asian weed E. pellucida. Previous records in Gran Canaria of the interesting and valuable native species Cladium mariscus and Cyperus michelianus now also seem to be referable to non-native, weedy look-alikes. 


\section{New Cyperaceae for Gran Canaria}

Cladium jamaicense Crantz, Inst. Rei. Herb. 1: 362, 1766 (Fig. 1, 2)

C. mariscus (L.) Pohl subsp. jamaicense (Crantz) Kükenthal

Barranco de Ayagaures, 150 m.s.m., 15.08.1956, E. Sventenius (ORT 7479);
Presa de Ayagaures, rochers humides contre le barrage, en bordure du lac, 24.12.1976, J. Duvigneaud 76Can753 (BR);

Arteara, au S de Fataga, rive droite du Barranco de Fataga, rochers suintants, 01.01.1977, J. Duvigneaud 76Can788 (BR);

Fataga, en amont du barrage de Fataga, 27.12.1977, J. Duvigneaud 77Can988 (BR, LG);

Barranco de Los Vicentillos (UTM 28R 0442 3081),

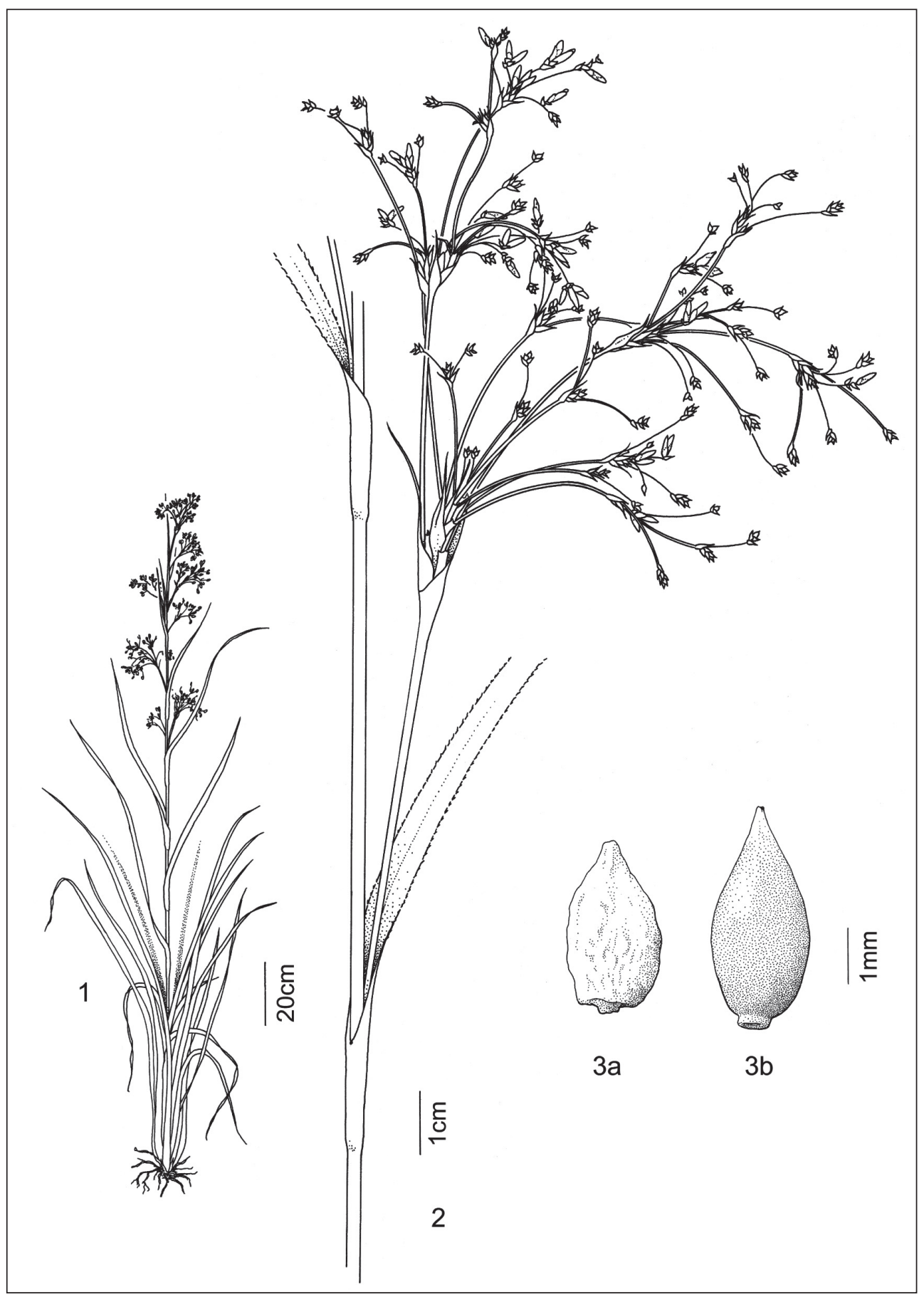

Fig. 1 - Cladium jamaicense from Gran Canaria (based on F. Verloove 9198): 1. General habit; 2. Partial inflorescence; 3A. Achene (C. jamaicense), 3B. Achene (C. mariscus; based on a herbarium specimen from the Balearic Islands, Spain). Drawings by Sven Bellanger. 


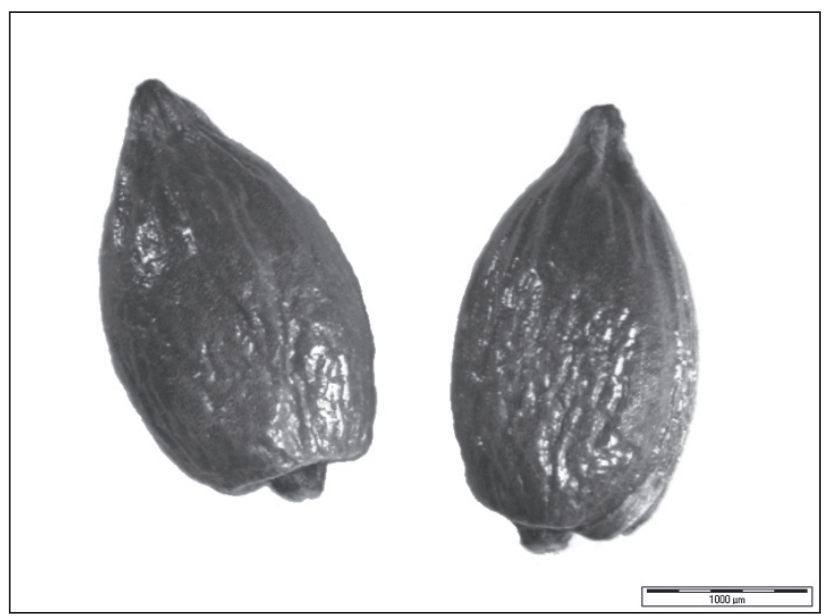

Fig. 2 - Cladium jamaicense from Gran Canaria (achenes), photo F. Verloove.

04.10.2000, J.A. Reyes-Betancort, S. Ávila \& M.V. Cabrera (TFC 42896);

Maspalomas towards Ayagaures, GC504 (km 3.54), Barranco de la Data, riverlet, locally abundant, 17.11.2011, F. Verloove 9198 (BR, LPA).

The following specimens have no or immature achenes but most likely also belong with Cladium jamaicense:

Maspalomas, 20.03.1947, E. Sventenius (ORT 7478);

Entre Ayagaures y Fataga, Rezumadero c. Barranco de Los Vicentes, 01.05.1979, P.L. Pérez (TFC 35157).

Cladium jamaicense is the (sub-) tropical counterpart of $C$. mariscus. It is believed to be originally confined to the New World (Kükenthal, 1942; Tucker, 2002; Songyun et al., 2010) while the latter is a native of the temperate regions of the Old World. However, a doubtfully distinct subspecies of the former, subsp. chinense (Nees) T. Koyama (syn.: C. chinense Nees), seems to be restricted to East Asia (Songyun et al., 2010). Cladium jamaicense has become a well-established weed in large parts of Africa (numerous references; for instance: Hoenselaar et al., 2010). In Macaronesia Cladium jamaicense is known so far from the Cape Verde Islands (Santo Antão and São Vicente; see Hansen \& Sunding, 1993; Arechavaleta et al., 2005). Other records of Cladium from the Atlantic Islands have always been unambiguously ascribed to C. mariscus s.str. (Hansen \& Sunding, 1993; Acebes Ginovés et al., 2009). In the Canary Islands it seems to be restricted to Gran Canaria.

Both species are tall (stem often exceeding 250 $\mathrm{cm})$, clump-forming perennials with strongly re-

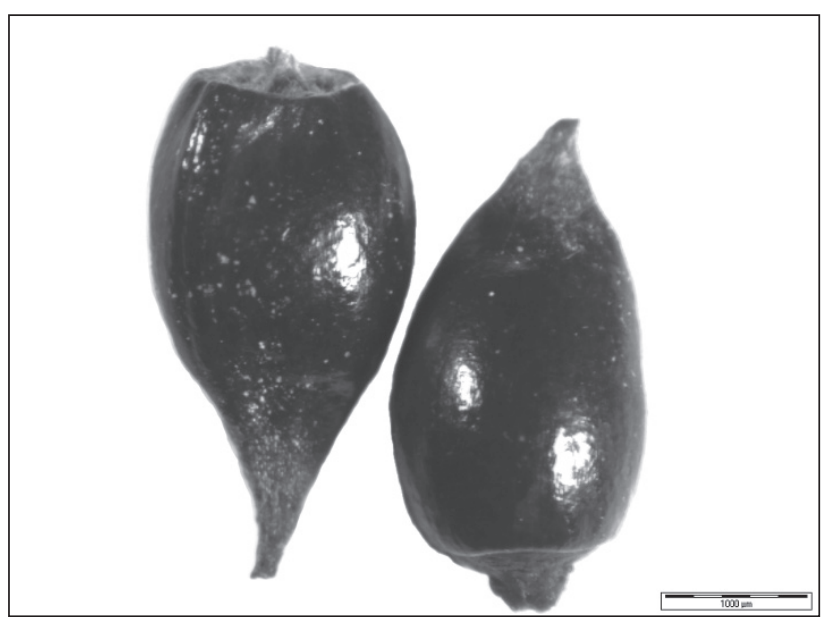

Fig. 3 - Cladium mariscus from Balearic Islands (achenes), photo F. Verloove.

trorsely scabrous leaf margins. They are opposed in the following couplet (see figs. 2, 3):

1 Achene rugose, pale brownish at maturity. Anthelae of the inflorescence diffuse with distinct, often flexuous branches Cladium jamaicense Achene smooth, dark brown to blackish at maturity. Anthelae of the inflorescence mostly clustered, without distinct branches (rarely more diffuse with distinct branches, especially in southern Europe) C. mariscus

Ripe achenes doubtlessly provide the best distinguishing feature between both species. The anthelae of the inflorescence are indicative but not decisive for their separation: they are always diffuse with distinct, flexuous branches in Cladium jamaicense. In Cladium mariscus the anthelae are usually congested but types with more diffuse inflorescences also occur, especially in southern Europe. Such plants have been distinguished as var. martii (Dufour ex Roem. \& Schult.) Kük. (syn.: C. mariscus subsp. martii (Dufour ex Roem. \& Schult.) Egor., C. martii (Dufour ex Roem. $\&$ Schult.) Richt.). However, they do not differ from Cladium mariscus s.str. in achene characters and are correctly included in its synonymy by recent authors (see for instance Castroviejo, 2007a).

The taxonomy of Cladium jamaicense is controversial. It was initially described as a species of its own by Crantz (1766). Kükenthal (1942) reduced it to subspecific rank under Cladium mariscus in his monograph of the Rhynchosporeae. He argued that both are well separated geographically but linked by an intermediate taxon in Australia (subsp. interme- 
dium Kük.). The latter is now sometimes accepted as a distinct taxon by Australian taxonomists, Cladium procerum S.T. Blake (e.g. Wilson, 1993). There is no agreement among recent authors about the taxonomic rank of the taxon here concerned. Most American authors tend to accept Cladium jamaicense as a distinct species (Tucker, 2002) and some Asian workers also do (see for instance Songyun \& al., 2010). However, in the Old World (sub-) tropics it is usually given subspecific rank (see for instance Kern, 1974; Gordon-Gray, 1995; Hoenselaar \& al., 2010).

The non-native status of Cladium jamaicense in the Canary Islands is obvious although Acebes Ginovés et al. (2009) accepted C. mariscus (subsp. mariscus) as "possibly native". It now seems that records of the latter from Gran Canaria are probably erroneous and in fact belong with Cladium jamaicense. This is in accordance with other records from southern Macaronesia (Cape Verde). If Cladium jamaicense effectively is a New World species (as presumed by Kükenthal (1942) and others), then it obviously is at most a naturalized xenophyte in the Atlantic Islands. Arechavaleta et al. (2005) came to the same conclusion for Cape Verde ("Introduzida segura”).

In Gran Canaria Cladium jamaicense locally builds dense, nearly monospecific stands on riverlet banks, mostly in barrancos. It often grows intermixed with the invasive environmental weed Cyperus involucratus Rottb.

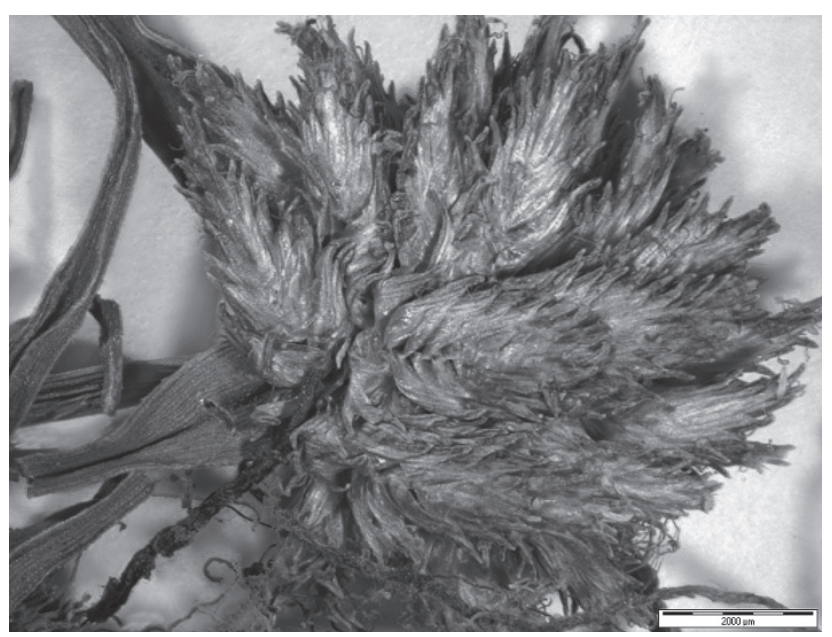

Fig. 4 - Cyperus pygmaeus from Gran Canaria (inflorescence), photo F. Verloove.
Cyperus pygmaeus Rottb., Descr. Icon. Rar. Pl. 20, 1773

Cyperus michelianus (L.) Link subsp. pygmaeus (Rottb.) Aschers. \& Graebn.

Dichostylis pygmaea Nees

Juncellus pygmaeus Clarke

Cueva de las Niñas, embalse de Cueva de las Niñas (Nside), pond margin, very common, 08.11.2011, F. Verloove 9219 (BR, LPA).

Cyperus pygmaeus is an enigmatic taxon, originally native in the warm-temperate and subtropical regions of the Old World. In general appearance it much looks like Cyperus michelianus but the phyllotaxy of the spikelets (an important feature at the generic level in Cyperaceae!) is very different: the glumes are distichously arranged in C. pygmaeus while they are spirally arranged in C. michelianus (Fig. 4, 5). On these grounds and despite their close resemblance both taxa have been accommodated in different genera in the past (Kern, 1974). Present-day authors adopt a more pragmatic taxonomy and accept both as members of Cyperus but at various taxonomic ranks: Kern (1974), Koyama (1985), Wilson (1993), Gordon-Gray (1995), Lye (1995), Lye (1997), Prasad \& Singh (2002), Songyun et al. (2010), etc. maintain its specific status, while others (for instance Kükenthal, 1935-36; Haines \& Lye, 1983; Simpson \& Koyama, 1998; Govaerts \& Simpson, 2007; Hoenselaar et al., 2010) reduce it to a subspecies of $C$. michelianus.

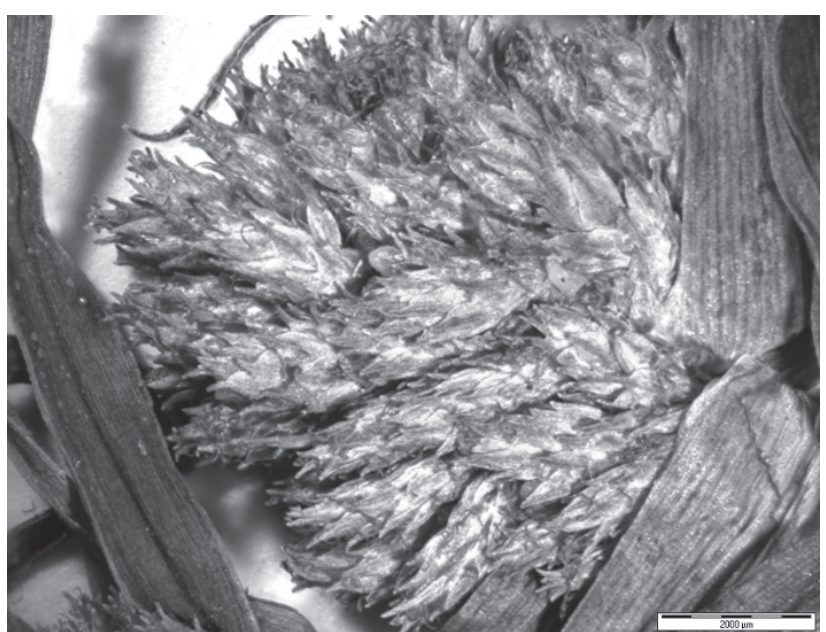

Fig. 5 - Cyperus michelianus from Huelva, Spain (inflorescence), photo F. Verloove. 
Both Cyperus pygmaeus and C. michelianus are tiny, tufted annuals with capitate inflorescences that are subtended by long bracts. They are best distinguished as follows (see also illustrations):

1 Glumes distichously arranged ..... Cyperus pygmaeus Glumes spirally arranged C. michelianus

Other characters are probably less stable or unreliable. Achenes tend to be slightly longer in Cyperus pygmaeus (usually at least $1 \mathrm{~mm}$ long, while they are usually less than $1 \mathrm{~mm}$ long in C. michelianus; Kukkonen, 1998). The style base seems to be epapillose in Cyperus pygmaeus but papillose in C. michelianus (Kükenthal, 1935-36). Contrary to Kükenthal 1.c. and Castroviejo (2007b) stigmas are usually two in number in both species (see also Kukkonen, 1998). Also in contrast with Kükenthal l.c. achenes are usually pale (yellowish brown), not maroon. Finally, stamens are usually 0-1 in number in Cyperus pygmaeus and 1-2 in C. michelianus.

Cyperus pygmaeus was recorded in abundance on the exposed margins of an artificial lake ("embalse") in Cueva de las Niñas. There is one previous record of "Cyperus michelianus" in Gran Canaria (Kunkel, 1967: "cerca de San Lorenzo, estanque seco"), apparently the only other record for the whole of Macaronesia. It is not unlikely that this record also belongs with Cyperus pygmaeus $^{1}$. If, as claimed by Kukkonen (1998), Cyperus pygmaeus and C. michelianus are indeed allopatric (with the former occurring from Greece and Algeria eastwards), then it should be regarded as a locally naturalized xenophyte in Gran Canaria (while Acebes Ginovés et al., (2009) suggested a possibly native status for $C$. michelianus). There are apparently no other records of Cyperus pygmaeus elsewhere in Macaronesia (Arechavaleta et al., 2005; Silva et al., 2005).

Kyllinga brevifolia Rottb., Descr. Icon. Rar. Pl. 13, 1773

Cyperus brevifolius (Rottb.) Endl. ex Hassk.

Arguineguín towards Patalavaca, barranco, lawn weed, very common, 10.11.2011, F. Verloove 9169 (BR, LPA).
Arguineguín towards Patalavaca, GC500 in front of Sun Wing Resort, lawn weed, 19.11.2011, F. Verloove 9175 (BR).

Kyllinga brevifolia is a pantropical weed (type from India). In the past decades it was able to spread to warm-temperate areas as well. In the Iberian Peninsula it is known from parts of Portugal and southern Spain (Castroviejo, 2007c). In Macaronesia Kyllinga brevifolia is widely naturalized in the Açores (Silva \& al., 2005). It was recently recorded for the first time in the Canary Islands from Tenerife (as a turf weed in a golf court; comm. A. Reyes-Betancort September 2010). The present records seem to be the first for Gran Canaria.

Kyllinga brevifolia was recorded in abundance in an irrigated public lawn close to the sea between Arguineguín and Patalavaca, along with Cyperus rotundus. In the vicinity it was also seen, in smaller numbers, in another public lawn. Its achenes are probably easily dispersed by lawn mowers; hence, its future (local) expansion is predictable.

\section{The case of Fimbristylis ferruginea in Gran Canaria}

Fimbristylis ferruginea (L.) Vahl was first recorded from Gran Canaria in 1973 (barranco de Ayagaures; Kunkel, 1978). In the very same area it was confirmed in November 2011 by the author. Elsewhere in Macaronesia it is only known from Cape Verde where it is accepted as "possibly native" (Arechavaleta et al., 2005). Fimbristylis ferruginea is part of a critical species complex that also includes, among others, $F$. sieberiana Kunth (syn.: F. ferruginea subsp. sieberiana (Kunth) Lye). Kukkonen $(1998,2001)$ found out that Fimbristylis ferruginea from Iran and Pakistan in fact belongs to a closely related, predominantly Asian species, F. turkestanica (Regel) B. Fedtsch. Spanish records were subsequently also referred to the latter species (Luceño \& Escudero, 2007). Eventually, all records of Fimbristylis ferruginea from the Euro+Med area, including those from Gran Canaria, were - perhaps uncritically - renamed as F. turkestanica (Jiménez-Mejías \& Luceño, 2011).

${ }^{1}$ Kunkel preserved a herbarium specimen (Kunkel 7601) but it is unknown where his herbarium is housed after his death. However, a record in the sorroundings of San Lorenzo from March 2012 (communicated by Rutger Barendse and Jeroen Willemsen) clearly represents Cyperus pygmaeus. 
Kukkonen 1.c. thoroughly discussed this issue but, surprisingly, did not emphasize the distinguishing features of Fimbristylis ferruginea (and F. sieberiana) on the one hand and $F$. turkestanica on the other hand. The latter was originally described from Taschkent by Regel (1881) as Isolepis turkestanica. The protologue is rather precise and describes a delicate, annual species $(3-14 \mathrm{~cm}$ tall) that most closely resembles Isolepis setacea (L.) R. Br. Kreczetovicz \& al. (1935) noted that Regels type specimen represented a poorly developed plant and included it in Fimbristylis ferruginea. Both the latter and Fimbristylis sieberiana were described as rather slender annuals with stems at most $30 \mathrm{~cm}$ long.

It is not impossible and perhaps even likely that Central Asian plants of Fimbristylis ferruginea indeed represent a distinct species that is best referred to as F. turkestanica. However, these plants hardly correspond with Fimbristylis ferruginea from Gran Canaria (and elsewhere in the subtropics); the latter is a coarse perennial with woody, short creeping rhizomes and stems up to $80 \mathrm{~cm}$ tall and by no means differs from collections from the Old World tropics (fide BR!). Thus, at least for the time being and pending a (longawaited!) worldwide revision of the Fimbristylis ferruginea-complex, plants from Gran Canaria are best ascribed to F. ferruginea s.l. and not to F turkestanica.

\section{REFERENCES}

ACEBES GINOVÉSJ.R.,LEÓNARENCIBIAM.C., RODRÍGUEZ NAVARROM.L., DELARCOAGUILARM., GARCÍA GALlO A., Pérezde PAZ P.L., Rodríguez Delgado O., MarTÍN OSORIO V.E. \& WiLDPRET DE LA TORRE W., 2009 - Pteridophyta, Spermatophyta. In: ARECHAVALETA M., RODRÍGUEZ S., ZURITA N. \& GARCÍA A. (eds.), Lista de especies silvestres de Canarias (hongos, plantas y animales terrestres). La Laguna: 119-172.

Arechavaleta M., Zurita N., MarRero M.C. \& MarTín J.L. (Eds.), 2005 - Lista preliminar de especies silvestres de Cabo Verde (hongos, plantas y animales terrestres). Consejería de Medio Ambiente e Ordenación Territorial, Gobierno de Canarias, Santa Cruz de Tenerife.

BRYSON C.T. \& CARTER R., 2008 - The significance of Cyperaceae as weeds. In: NACZI R.F.C. \& FORD B.A. (Eds.), Sedges: uses, diversity and systematics of the Cyperaceae. Monogr. Syst. Bot. Missouri Bot. Gard. 108: 15-101.

Castroviejo S., 2007a - Cladium. In: Castroviejo S. et al. (Eds.), Flora Ibérica, vol. 18. Cyperaceae-Ponteder-
On account of the relatively open inflorescence with most spikelets on (long) peduncles, the membranous, hairy (not coriaceous and glabrous) leaf sheaths, the long leaf blades (10-30 cm long), the rather obtusish spikelets, the broader style base and the relatively larger achenes they will probably turn out to belong with Fimbristylis sieberiana.

The presence of Fimbristylis ferruginea in Gran Canaria was confirmed in November 2011 but it seems to be naturalized only locally between Maspalomas and Ayagaures. A few plants were recorded by a riverlet in Barranco de la Data along road GC504 (between km 3.5-4) with, among others, Cladium jamaicense, Cyperus involucratus Rottb. and C. laevigatus L. It was more numerous on the exposed banks of an artificial lake (embalse) in Ayagaures, intermixed with the much more frequent Fimbristylis bisumbellata (Forssk.) Bub.

\section{Acknowledgements}

Alfredo Reyes-Betancort (Puerto de la Cruz, Tenerife, Spain) revised the herbaria ORT and TFC for Cladium and provided relevant data. Sven Bellanger (drawings) and Iris van der Beeten (photos) (both Meise, Belgium) prepared the illustrations.

iaceae. Real Jardín Botánico, CSIC, Madrid: 102-104.

Castroviejo S., 2007b - Cyperus. In: CASTROVIEjo S. et al. (Eds.), Flora Ibérica, vol. 18. Cyperaceae-Pontederiaceae. Real Jardín Botánico, CSIC, Madrid: 8-27.

CASTROVIEjO S., 2007c-Kyllinga. In: CASTROVIEjO S. et al. (eds.), Flora Ibérica, vol. 18. Cyperaceae-Pontederiaceae. Real Jardín Botánico, CSIC, Madrid: 32-34.

CrantZ H.J.N., 1766 - Institutiones Rei Herbariae. 1. Viennae.

GORDON-GRAY K.D., 1995 - Cyperaceae in Natal. Strelitzia 2: 1-218.

GOVAERTS R. \& SIMPSON D.A., 2007 - World checklist of Cyperaceae. Royal Botanic Gardens, Kew: XIII + 765 p.

HAINES R.W. \& LYE K.A., 1983 - The sedges and rushes of East Africa. East African Natural History Society, Nairobi: $404 \mathrm{p}$.

HANSEN A. \& SUNDING P., 1993 - Flora of Macaronesia. Check-list of vascular plants ( $4^{\text {th }}$ revised edition). Sommerfeltia 17. Oslo. 
Hoenselaar K., Verdcourt B. \& Beentje H.J., 2010 Cyperaceae. In: BEENTJE H.J. (Ed.), Flora of Tropical East Africa. Royal Botanic Gardens, Kew: 467 p.

JiMÉNEZ-MEJÍAS P. \& LUCEÑO M., 2011 - Cyperaceae. In: VV. AA. (Eds.), Euro+Med Plantbase - the information resource for Euro-Mediterranean plant diversity. Accessed on line: http://ww2.bgbm.org/EuroPlusMed/ PTaxonDetailOccurrence. asp? NameId=60965\&PTRef $\mathrm{Fk}=7400000$ (December 2011).

KERN J.H., 1974 - Cyperaceae. In: VAN STEENIS C.G.G.J. (Ed.), Flora Malesiana, vol. 7(3): 435-753. Noordhoff, Leiden.

KOYAMA T., 1985 - Cyperaceae. In: DASSANAYAKE M.D. \& Fosberg F.R. (Eds.), A revised handbook to the flora of Ceylon. 5. Amerind Publishing Co. Pvt. Ltd., New Delhi: 125-405.

KRECZETOVICZ V.I., ROSHEVITZ R.Y., SERGIEVSKAJA L.P., SCHISCHKINB.K.,ZINSERLINGG.D.\&JUZEPCZUKS.V., 1935 - Cyperaceae. In: SCHISCHKIN B.K. (Ed.), Flora URSS. 3. Academy of Sciences of the USSR, Leningrad: Pp. 1-464.

KÜKENTHAL G., 1935-1936 - Cyperaceae. In: ENGLER H.G.A. (Ed.), Das Pflanzenreich. 101 (IV.20): 1-671. Engelmann, Berlin.

KÜKENTHAL G., 1942 - Vorarbeiten zu einer Monographie der Rhynchosporoideae. XI. 10. Cladium Crantz. Repert. Spec. Nov. Regni Veg. 50: 1-17, 139-193.

KUKKONEN I., 1998 - Cyperaceae. In: RECHINGER K.H. (ed.), Flora Iranica 173. Akademische Druck- und Verlagsanstalt, Graz: 1-307.

KUKKONEN I., 2001 - Cyperaceae. In: ALI S.I. \& QAISER M. (Eds.), Flora of Pakistan. 206: 1-277. University of Karachi, Karachi \& Missouri Botanical Garden, St. Louis.

KUNKEL G., 1967 - Plantas vasculares nuevas para la flora de Gran Canaria. Quad. Bot. 1: 3-23.

KUNKEL G., 1978 - An excursion through my herbarium - II. Vieraea 8: 337-364.

LUCEÑO M. \& ESCUDERO M., 2007 - Fimbristylis. In: CASTROVIEJO S. et al. (Eds.), Flora Ibérica, vol. 18. Cyperaceae-Pontederiaceae. Real Jardín Botánico, CSIC, Madrid: 94-97.

LYE K.A., 1995 - Cyperaceae. In: THULIN M. (Ed.), Flora of Somalia 4: 112-145. Royal Botanic Gardens, Kew, Great Britain.
LYE K.A., 1997 - Cyperaceae. In: EDWARDS S. et al. (Eds.), Flora of Ethiopia and Eritrea. Addis Ababa, Ethiopia and Uppsala Sweden.

MABBERLEY D.J., 2008 - Mabberley's plant-book (3th ed.). Cambridge University Press, Cambridge: XVIII $+1021 \mathrm{p}$.

PRASAD V.P. \& SINGH N.P., 2002 - Sedges of Karnataka (India) (family Cyperaceae). Journ. Econ. Taxon. Bot., Add. Ser. 21: XI + $354 \mathrm{p}$.

Regel A., 1881 - Juncacearum, Cyperacearum, Graminearum, Balanophorearum et Acotyledonearum vascularium centrasiaticarum adhuc cogmtarum enumeratio. Trudy Imp. S.-Peterburgsk. Bot. Sada 7: 552-666.

Silva L., Pinto N., Press B., Rumsay F., Carine M., HENDERSON S. \& SJÖGREN E., 2005 - Lista das plantas vasculares (Pteridophyta e Spermatophyta). In: Borges P.A.V. et al. (Eds.), Listagem da fauna e flora (Mollusca e Arthropoda) (Bryophyta, Pteridophyta e Spermatophyta) terrestres dos Açores: 131-156.

SIMPSON D.A. \& INGLIS C.A., 2001 - Cyperaceae of economic, ethnobotanical, and horticultural importance: a checklist. Kew Bull. 56: 257-360.

SiMPSON D.A. \& KOYAMA T., 1998 - Cyperaceae. In: SANTISUK T. \& LARSEN K. (Eds.), Flora of Thailand 6(4): 247-485.

SONGYUN L., BRUHLJ.J. \& WILSON K.L., 2010-Cladium. In: Wu C.-Y. et al. (Eds.), Flora of China 23: 258-259.

TUCKER G.C., 2002 - Cladium. In: Flora of North America Editorial Committee (Eds.), Flora of North America 23: 240-242. Oxford University Press, Oxford.

VerloOve F., 2010a - Invaders in disguise. Conservation risks derived from misidentifications of invasive plants. Management of Biological Invasions 1: 1-5.

VerloOVE F., 2010b - Studies in Italian Cyperaceae: 1. Eleocharis pellucida, new to Europe, naturalised in Piemonte. Webbia 65(1): 133-140.

VerloOve F. \& SÁNCHEZ Gullón E., 2010 - Further notes on Cyperaceae in the Iberian Peninsula: corrections, adjustments and additions. Fl. Medit. 20: 141-147.

VERLOOVE F. \& SOlDANO A., 2011 - Studies in Italian Cyperaceae: 2. Miscellaneous notes. Webbia 66(1): 69-75.

WILSON K.L., 1993 - Cyperaceae. In: HARDEN G.J. (Ed.), Flora of New South Wales 4: 293-396. Royal Botanic Gardens, Sydney.

Summary: Recent fieldwork and additional herbarium research on some critical Cyperaceae from Gran Canaria (Canary Islands, Spain) revealed some interesting facts. Previous claims for the supposedly native species Cladium mariscus and Cyperus michelianus are, at least in part, erroneous and ascribable respectively to the non-native species $C$. jamaicense and C. pygmaeus. Kyllinga brevifolia is cited for the first time from Gran Canaria as a locally established turf weed. Finally, the identity of Fimbristylis ferruginea in Gran Canaria is thoroughly discussed. 
